Localities, Vol. 4, 2014, pp. 7-49

\title{
Mobile Localities Beyond Monocultures of the Mind
}

\section{Diana Brydon}

Professor, Department of English, Film, and Theatre, University of

Manitoba

E-mail: diana.brydon@umanitoba.ca

\section{Abstract}

Employing insights from contemporary postcolonial, decolonial, and indigenous theory, this article argues that home, identity, and the politics of naming "here" are emerging as complex "mobile localities" with implications for how a globalizing world is understood. The Cartesian reasoning that enabled Eurocentric perspectives to lay sole claim to universality is now being challenged by decolonizing views that understand locality through a framework more closely attuned to what Boaventura Sousa de Santos calls "an ecology of knowledges." To hold to a single definition in a globalizing world increasingly marks a failure of imagination: a "monoculture of the mind" in a multicultural world. For many, locality may now be a form of translocality, in which alternative understandings of space and time co-exist, sometimes only concurrently, and sometimes mingling to form emergent understandings. The paper interprets two contemporary Canadian texts involved in renegotiating urban civic space--Cree poet Marvin Francis's City Treaty: A Long Poem and Trinidadian-Canadian Dionne Brand's What 


\section{Diana Brydon}

We All Long For: A Novel -with the aim of providing a revised model for understanding locality in a globalizing world. Revisions of the local such as those offered by Brand and Francis reveal the potential for understanding locality as a living, moving, metamorphizing space rather than a determinant place of origin.

Keywords: Locality, Translocality, Mobility, Decolonial, Indigenous, Postcolonial, Canada.

\section{Introduction: "I am where I think" (Walter Mignolo); "Where is Here?" (Northrop Frye)}

This article suggests how reading these two quotations together can illuminate contemporary understandings of what locality means under globalizing changes. ${ }^{1}$ In particular, from my own position within the Americas, I consider how indigenous understandings of the agency of place are finding resonance within contemporary scientific recognitions of the agency of things previously deemed to be without agency. I begin by unpacking the key terms of my title and their implications for how locality might be rethought from decolonizing perspectives, using my home city, Winnipeg, and my home country, Canada, as examples.

1) The research for this paper was undertaken, in part, with support from the Canada Research Chairs program. I am grateful to the conference organizers of "The Locality of Alterity and Symbiosis," held June 19-20, 2014, for the opportunity to deliver an earlier version of this paper and benefit from the penetrating questions of colleagues in the audience. I also thank my research assistant, Chigbo Arthur Anyadubya, for his support. 
I explain how Canada is increasingly being described as a particular type of settler colony, in recognition of the fact that it was already settled by indigenous peoples when, like the rest of the Americas, it was first "discovered" by European adventurers. After sections on home, identity, and the politics of naming "here" as a complex chronotope ${ }^{2}$ and "mobile locality," ${ }^{3}$ I turn to some literary examples of new urban imaginaries, which move beyond Saskia Sassen's "global cities" model in their tracking of alternative routes through the reterritorializing cosmopolitan city ${ }^{4}$, to challenge what Gayatri Chakravorty Spivak ${ }^{5}$, borrowing from Vandana Shiva, has deplored as a "monoculture of the mind"6. The Cartesian perspective on the world that enabled Eurocentric perspectives to lay sole claim to universalityis now being challenged by postcolonial and indigenous perspectives that show locality in new lights. The article concludes with brief interpretations of indigenous Cree poet Marvin Francis's City Treaty: A Long

2) Caryl Emerson and Gary Saul Morson explain that "A genre's complex of possible or likely actions constitutes its chronotope, and Bakhtin analyzes and traces the history of diverse generic chronotopes, which are themselves always becoming and changing" (93). See their entry, "Bakhtin, Mikhail" In The Johns Hopkins Guide to Literary Theory \& Criticism. Second Edition. (Ed.), Michael Groden, Martin Kreiswirth, and Imre Szeman. 2005. Baltimore and London: The Johns Hopkins University Press, pp.89-95.

3) Leigh K. Jenco, 2011. Recentering Political Theory: The Promise of Mobile Locality, Cultural Critique, 79. pp. 27-59.

4) I borrow this phrasing from Emily Johansen.

5) Gayatri Chakravorty Spivak, 2012. An Aesthetic Education in the Era of Globalization, Harvard University Press.

6) Vandana Shiva, 1993. Monocultures of the Mind, Trumpeter, p.25.

I thank Walter Mignolo for pointing out this earlier usage of the term by Vandana Shiva 
Poemand Trinidadian-Canadian Dionne Brand's What We All Long For: A Novel, each read as locally-based Canadian texts that move toward enacting what Boaventura Sousa de Santos has called "an ecology of knowledge"7 framework.

The implications of recognizing the importance of locality in shaping perception and evaluation are profound and still being worked through across the full range of disciplinary practices. We know, for example, that local languages and religious practices were banned throughout the colonies during the times of the British Empire. They were banned as well for indigenous peoples in settler colonies such as Canada. Attempts to reconnect with those suppressed traditions are in many places still in their infancy and they are only slowly entering the academy to change research protocols and curricular design. Today, global university ranking systems and citational indexes remain skewed by the dominance of the Anglosphere and its assessment of what is interesting and important. Some localities still count more than others. Anglophone Canadians enjoy a linguistic advantage within this system but the arbiters of the system show little interest in Canadian topics or Canadian perspectives on global issues. This global higher education regime seems deeply entrenched, but its purchase on the imaginations of all those marginalized by its narrowness is waning. Critics have sought to respond to this situation by moving away from merely opposing

7) Boaventura de Sousa Santos, 2007. Another Knowledge is Possibl: Beyond Northern Epistemologies, London: Verso. 
local and global, toward urging people to act locally while thinking globally, or by attending to a "territorializing cosmopolitanism [that] allows for a consideration of the everyday experience of global connections in local places, and the cosmopolitical ethics that emerge from this recognition."8 This is the context in which I put Mignolo's rephrasing of the Cartesian formula in dialogue with a famous question once put by Canadian theorist Northrop Frye-famous in Canada, that is, which is my point. Frye is famous globally for his work on the Bible, literature and literary theory, but not for his statements about Canada.

\section{If I am Where I Think, Where is That? "Where is Here?" (Frye)}

The old vocabularies are failing us. Words take on new meanings in new contexts; new words are coined to capture new understandings. In a globalizing world, everyone needs to be aware of multilingual possibilities, and the ways that even apparently simple words like here, where, and home resonate differently in different translational contexts of experience, language, and locality. Each word carries assumptions about how we know and live in the world. To hold to a single definition in a globalizing world increasingly marks a failure of imagination: a

8) Emily Johansen, 2014. Cosmopolitanism and Place: Spatial Forms in Contemporary Anglophone Literature, London: Palgrave Macmillan, p. 3. 
"monoculture of the mind"9 in a multicultural world. To talk across our differences, few feminists still dream, with Adrienne Rich in an earlier time, of "a common language"10; instead, our dreams are more likely to follow Suniti Namjoshi, in "building babel" - the title of an experimental novel that leaves its conclusions open to her readers. Once intended as a punishment for a disobedient world, Babel separated people into many discrete monocultures of the mind, yet that multiplicity of languages is now being reinterpreted and embraced as offering a richer and truer encounter with the world's diversity. These changes are about more than words in themselves; they involve conflicting understandings about the ways words connect to the world, inhabit a world, and reach out to other worlds. These are debates about the ways in which overlapping and separated communities of people make meanings. Anna Lowenhaupt Tsing writes of "zones of awkward engagement, where words mean something different across a divide even as people agree to speak"11. Such a world constituted the treaties signed between indigenous First Nations and the British Crown in places now called Canada.

The term First Nations was adopted in the late twentieth century to stress the indigenous prior settlement of the land and prior governance arrangements for managing it. Too often those

9) Spivak, An Aesthetic Education, p. 25.

10) See Janet Neigh, 2014. Dreams of Uncommon Languages: Transnational Feminist Pedagogy and Multilingual Poetics, Feminist Formations 20.1. pp.70-92.

11) Anna Lowenhaupt Tsing, 2005. Friction: An Ethnography of Global Connection Princeton: Princeton University Press, xi. 
zones represented by the treaties have proved sites of epistemic violence, where only one, Eurocentric interpretation prevailed. The nation-state now called Canada, but in a smaller geopolitical configuration, officially came into existence through the British North America Act in 1867. The Constitution was repatriated from Britain in 1982. That past led some to describe Canada's history as marking a trajectory from colony to nation. Originally the territory of many different groups of indigenous peoples, the land was colonized by French and British fur traders and settlers who visited and gradually moved into the country up the St. Lawrence River on the east but also from the west coast after visits from explorers such as George Vancouver. In their wars with each other, and during the American War of Independence, both the French and the English formed alliances with native nations. Treaties, signed by the Crown with many of these indigenous peoples, although not always honoured, continue to form a legal basis for governance arrangements among those who signed. In response to indigenous activism, the Canadian national identity has moved from stressing a bicultural French/English foundation toward understanding Canada as a "treaty nation" formed by three founding groups of peoples, with indigenous nations joining the French and English as founders of the new nation that arose from their interactions. That focus on foundational narratives, in turn, is being challenged by a multitude of others, whose participations from the nation's earliest days were erased, such as African-Canadians (who came enslaved and 
free) and Asian Canadians (who came to build the railroad), and by those from many other parts of the world who came, and continue to come, to make Canada their home. Since a nationstate is composed of its peoples, and Canada has always been a multi-nation state, formed by successive patterns of immigration, the identity of the nation-state itself is continually under renovation.

Because of the importance of these treaties in shaping indigenous/newcomer relations, contemporary theorists are now re-reading them to retrieve previously silenced perspectives, as does Aimée Craft in Breathing Life Into the Stone Fort Treaty: An Anishinabe Understanding of Treaty One. Francis's poem City Treaty may be read as the poetic equivalent of this act of historical reinterpretation. ${ }^{12}$ Implicit in such attempts to retrieve what Jamaican writer Erna Brodber has termed the "half [that] has never been told"13 as a result of colonialism, is the urgent question: givencontexts of epistemic violence, how might cognitive justice be imagined?

To focus on epistemic violence is not to downplay other forms of institutional and physical violence but it is to recognize how intertwined they are. If they are to be disentangled, then epistemic issues cannot be ignored. Spivak argues that "the world needs an epistemological change that will rearrange

12) see also McLeod on how Cree narrative memory works: "Narratives are constantly being reinterpreted and recreated in light of shifting experience and context" (11). "Open-endedness" is a central feature of this process (13).

13) Erna Brodber, 1988. Myal, London: New Beacon, p.35. 
desires." ${ }^{14}$ Such a change is needed to escape the prison-house or mental straitjackets of any single "monoculture of the mind"15. In 1963, Guyanese novelist Wilson Harris argued the need to recognize "the offspring of a harlequin cosmos at the heart of existence"16. Now, Portuguese theorist Boaventura de Sousa Santos and his colleagues advocate embracing "an ecology of knowledge," rethinking globalization from below, to create a diversality that is mediated through and out of local knowledge in relations of circulation and exchange rather than domination and exclusion. The idea of the ecology of knowledge owes much to Latin American indigenous cosmologies and the critique of European modernity provided by Latin American decolonial thinkers. In this model, diversality replaces universality. But diversality is not cultural relativism. It involves a more radical rethinking of the fundamental building blocks of contemporary thinking, starting with rejecting many of the naturalized binaries that form the common sense of both everyday and specialized disciplinary thinking: nature/culture; human/not-human; local/global. In this sense, it can be compared to theories of critical multiculturalism, which reject understandings of cultures as fixed and bounded. These theories stress how culture functions "in people's real lives: dynamic, polyvalent, and contestable"17.

14) Spivak, An Aesthetic Education, p. 2.

15) Spivak, An Aesthetic Education, p. 25.

16) Wilson Harris, 1983. The Womb of Space: the Cross-Cultural Imagination, London: Greenwood, pp. 92-93.

17) LuMing Mao, 2013. Beyond Bias, Binary, and Border: Mapping out the Future of 
Much postcolonial and feminist theory agrees that "the questions of where one thinks from, with whom, and for what purpose become themselves important elements of social science and humanities thinking..."18 Attention to how situation matters is now part of most disciplinary practices, but what matters even more is how that attention is paid and how that practice is understood. Self-reflexivity and vigilance are now part of how many of us work in these fields. But on their own, they may not prove sufficient. Mignolo, studying modernity from a Latin American decolonial ${ }^{19}$ location, dislodges Descartes' claim, "I think therefore I am," rephrasing it from his own decolonial perspective to argue: "I am where I think"20 (In Lionnet \& Shih 2012: location 397). Francoise Lionnet and Shu-mei Shih elaborate Mignolo's rephrasing to explain how it recognizes the "intimate

Comparative Rhetoric, Rhetoric Society Quarterly 43.3 p. 214.

18) Arturo Escobar, 2010. Afterword to Globalization and the Decolonial Option, Walter D. Mignolo and Arturo Escobar (eds.), London: Routledge, p. 392.

19) In Mignolo's Introduction to Globalization and the Decolonial Option, Walter D. Mignolo and Arturo Escobar, (eds.), 2010. Routledge, Mignolo offers decolonial thinking as an alternative to both postcolonial theory and contemporary capitalist imaginaries. He explains: "The de-colonial option in epistemology and politics requires a different kind of thinking ... a non-linear and chronological (but spatial) epistemological break; it requires border epistemology (e.g. epistemic disobedience), a non-capitalist political economy, and a plural-national (that is, non-mononational) concept of the state" (2). William D. Coleman and Alina Sajed, in Fifty Key Thinkers on Globalization, (Routledge 2013) explain decoloniality as "a movement led by a globally linked political society pursuing various projects anchored in local communities having in common their delinking from modernity in a search for trans-modern lives" (162).

20) Walter D. Mignolo, 2011. I am Where I Think: Remapping the Order of Knowing, in The Creolization of Theory, Francoise Lionnet and Shu-mei Shih, (eds.), Durham: Duke : University Press, pp. 159-192. 
connection among biography ('I am'), geography ('where'), and knowledge ('I think')." Mignolo's riddle disrupts the borders separating these disciplinary categories to suggest how entangled they are and to problematize any automatic understanding of who, what, and how of the "I." According to Lionnet and Shih, Mignolo exposes "the pretensions to universality of Western thought" and activates "a process of epistemic democratization, which is also a movement toward 'pluriversality'." Pluriversality, to be fully realized, requires transversal exchanges, movements involving intercultural dialogue "from periphery to periphery"21. This double movement linking pluriversality (or diversality) to transversality challenges ethnocentric assumptions about meaning and how it is made. In these ways, "I am where I think" marks a new way of thinking the local and thinking out of the local-- but finding the words to convey that understanding is not easy. I take that task to be part of the challenge addressed by the journal, Localities, and the conferences run by the Center for Locality and Humanities at Busan University.

In the mid twentieth-century, Canadian critic Northrop Frye wrote: "It seems to me that the Canadian sensibility has been profoundly disturbed, not so much by our famous problem of identity, important as that is, as by a series of paradoxes in what confronts that identity. It is less perplexed by the question 'Who

21) Enrique D. Dussell, 2012. Transmodernity and Interculturality: An Interpretation from the Perspective of Philosophy of Liberation, Transmodernity Journal of Peripheral Cultural Production of the Luso-Hispanic World 1.3 p. 54. 
am I?' than by some such riddle as 'Where is here?'"22 For Frye, this was a specifically Canadian question, generated out of European colonization of a foreign environment, followed by rapid technological developments that did not allow the newcomers time to acclimatize to their new home. Nor were they able to see the land's traditional inhabitants, the indigenous peoples, as anything other than primitives. Frye writes of one of Duncan Campbell Scott's mid $20^{\text {th }}$ century poems about Canadian indigenous peoples: "In English literatures we have to go back to Anglo-Saxon times to encounter so incongruous a collision of cultures." ${ }^{23}$ Postcolonial theorists reject the collision of cultures model, and the assumptions that deny the coevolves of different cultural systems. These imperialist models situated the systems devised by the indigenous cultures of the Americas in a model that assumed they were only congruent with a European past.

Nowadays, as theorists debate globalization and planetary, offering models of deeper global history, to go back to AngloSaxon times seems much less of a leap. Frye's riddle now takes on new resonance. "Where is here?" is no longer simply a national question for settler colonial Canada. It is also now a world- and time-spanning question. "Here" is a complicated chronotope. When I was younger, I was impatient with Frye's framing of this question but now that I am older, I appreciate its

22) Northrop Frye, 1945. Conclusion to a Literary History of Canada, The Bush Garden: Essays on the Canadian Imagination, Toronto: UTP.

23) Frye, Conclusion to a Literary History of Canada. 
complexity. At the turn of the last century, I argued against critics who read Frye's riddle (despite his disclaimer) as essentially an identity question. I claimed instead that the real question has always been "What are we doing here?"24, meant as a double-edged question drawing attention to settler colonial guilt and the need for "a new set of questions" that might attend to how the nation could collectively devise a more ethically responsible future. I argued, "With our choices, we position ourselves; our actions are constrained but not predetermined by our location" and cited Paul Gilroy (himself citing a popular song of the day): "It ain't where you're from, it's where you're at."25 "Where you're at," this colloquial rephrasing of "here" to indicate, not a taken-for granted location but rather an active orientation to the production of place, is what links Mignolo's statement to Frye's question.

In the current era, during a time globalization theorist Ulrich Beck describes as one of "transnational place polygamy," 26 the place where one thinks isnot so easy to describe. Some metaphors fail us. I am fascinated by the phrase, "place polygamy," because it encapsulates so many entangled assumptions about gender, belonging, loyalty, heterosexuality, and taboo. The metaphor revisits outdated assumptions: of one place, one language, one home, where the relation of person to place is made analogous to

24) Diana Brydon, 2000. It's Time for a New Set of Questions, Essays in Canadian Writing 71, p. 54.

25) Brydon, It's Time for a New Set of Questions, p. 54.

26) Ulrich Beck, 2000. What is Globalization?, Malden: Polity, p. 73. 
a woman's marriage. (Beck came up with the phrase when seeing a woman with double national loyalties). It offers credence to Bonnie Honig's observation of "the prominence of marital metaphors for citizenship"27. By invoking polygamy, Beck's metaphor, whatever his intention, implies there is something scandalous about more complex relations of affiliation and belonging. ${ }^{28}$ Yet for many, locality may now take form as either locality ${ }^{29}$ or translocality, in which alternative understandings of space and time co-exist, sometimes only concurrently, and sometimes mingling to form emergent understandings.

Contemporary Winnipeg, and contemporary Canada, are such places, places where indigenous and immigrant cultures continue to interact, and where a deep awareness of place causes poets, such as Marvin Francis, to narrate "the risky birth of muskeg metaphor"30 erupting beneath the pavements of the city, his purpose to renegotiate civic space with contending national and global imaginaries. Muskeg is the perfect metaphor for complex northern mobile imaginaries. A word of Cree origin, it describes an unstable, spongy, and waterlogged soil composed of many

27) Bonnie Honig, 2001. Democracy and the Foreigner Princeton: Princeton University Press, p. 112.

28) I explore these implications fully in Brydon, 2006. A Place on the Map of the World: Locating Hope in Shani Mootoo's He Drown She in the Sea and Dionne Brand's What We All Long For, MaComère 8, pp. 94-110.

29) Roland Robertson introduced the concept of "glocalization" to challenge views that separated local from global as completely autonomous spaces, arguing instead that they were more properly seen as mutually constitutive under globalization.

30) Marvin Francis, 2002. City Treaty: A Long Poem, Winnipeg: Turnstone, p. 58. 
layers. My university President now opens every speech by acknowledging the city's multi-layered history: it is Treaty One Territory, at the crossroads of the Anishinabe, Métis, Cree, Dakota and Oji Cree Nations. The Red River Métis are an officially recognized distinct people deriving from intermarriage between indigenous Cree and French and Scottish traders, who established their own government under the leadership of Louis Riel in what is now Manitoba, in the Red River Valley, in 1869. This initiative was put down as a rebellion by the new Canadian government in the East, and Riel was hanged. But now Riel is remembered as a hero and we celebrate a provincial holiday in his name. As a settler colony, Canada has always welcomed immigration and since the end of the Second World War has opened itself to more diverse streams of immigration. Under Prime Minister Trudeau, Canada officially embraced its identity as a multicultural nation. Winnipeg, in the physical centre of the country, welcomes many new immigrants from all over the world each year. From out of this location, a meeting place of indigenous, multicultural, transcultural, and decolonial imaginaries, the rest of this paper will developrevised models for working out of locality and through locality today.

\section{Home}

With the rise of globalization, many are asking about how we might see the world in its entirety as our home. Spivak offers 
planetary as a counter to global. ${ }^{31}$ Edward Said writes of the necessity of worldliness. For Spivak, planetarity involves an alternative logic to that of transnational capital, which may be achieved through developing "transnational literacies"; that is, alternative modes of meaning-making attentive to differences and also complicities. Her utopianism contrasts with Said's worldliness, which involves a type of secular humanism that enables "contrapuntal reading." Such readings attend to both dominant metropolitan logics and those of the versions of reality they have subjugated. Mignolo advocates a critical cosmopolitanism achieved through "border thinking," which attends to the contact zones between communities where alternative modes of understanding may co-exist. Beck advises replacing "methodological nationalism," which assumes the bounded nation as a starting point, with "methodological cosmopolitanism," a mode of thinking across such borders. At the same time, still others draw attention to the rise of "global cities" (Sassen) and regional configurations such as the European Union. In the Preface to Trajectories: Inter-Asia Cultural Studies, Kuan-Hsing Chen points to the originality at the time-1998-of problematizing "the historical formations of

31) As Coleman and Sajed explain, "Spivak sees globalization as the unification of the globe by the market" (227), In Death of a Discipline: Columbia University Press (2003), she offers planetary as an alternative, which is perhaps "best imagined from the precapitalist cultures of the planet" (101). She writes that she "cannot offer a formulaic access to planetary, No one can" (78). Her refusal to fully define the term leaves it open for further development, including interpretations that may work against its grain, retrieving it for environment modernist interpretations Spivak might wish to reject. 
cultural studies in different geo-political contexts" 32 . Whereas previously academics might have assumed their contexts to "be somewhat universal or dominantly important" or on the other hand, gone "nativist, with no sense of the infiltration of global political and economic forces," 33 the stance in this volume, he writes, was to acknowledge "coming from 'the local' but with a sense of the international/global"34. In other words, it is time to refuse the binary that sees non-Western practices "as particular to their sites of origin" and Western practices as universal, as applicable everywhere. ${ }^{35}$ What happens to understandings of home in such new configurations of situation?

Few of us feel the need to look up "home" in a dictionary, yet if we do, we find it a fascinating topic. Raymond Williams did not include home in his Keywords in 1976. Yet it does appear in Tony Bennett et al's New Keywords in 2005. Why does home appear as a new keyword requiring extended definition now? Bennett's entry on home begins to suggest an answer. Home mediates relations "between rest and movement, private and public," here and there. ${ }^{36}$ These are relations that appear to be disrupted by processes of globalization in ways that remain in

32) Kuan-Hsing Chen(ed.), 1998. Introduction to the Decolonizing Question, Trajectories: Inter-Asia Cultural Studies, London: Routledge, xv.

33) Chen, introduction, xv-xvi.

34) Chen, xv.

35) For the implications of such a shift for translation theory, See Judy Wakabayashi, 2014. "Response" in "Translation Studies Forum: Universalism in Translation Studies," Translation Studies 7.1, pp. 97-101.

36) Tony Bennett, Lawrence Grossberg, and Meaghan Morriss,(eds.) 2005. New Keywords: A Revised Vocabulary of Culture and Society, Oxford: Blackwell, p. 163. 
dispute..$^{37}$ They operate at the micro-levels of family and the macro-levels of broader forms of community. The Dictionary of Untranslatable, very much a book of our time, explores the tensions between what it calls the ontological Heimat (literally home) and the genealogical Vaterland (Fatherland) to worry about the ways these concepts may both enfranchise and disenfranchise national belonging, with the even more problematic unheimlich, inadequately translated into English as uncanny or unhomeliness, pointing to the instability at the heart of the homely. ${ }^{38}$ Salman Rushdie captures this dilemma well when he repeatedly points to the ambivalence of Dorothy's magic chant at the end of the Hollywood movie, The Wizard of Oz: "there's no place like home." ${ }^{39}$ For Rushdie, the longing to leave home is as strong as the dream of finding a home where dreams might come true. At the same time, there literally is no place like home because that kind of home, an ideal of home, does not exist as a place at all. ${ }^{40}$

Spivak explains the complexity of home for her thinking by pointing to its untranslatability across languages: "The word ghar

37) A version of these five sentences appears in Brydon, "Migrating Literacies: Redefining Knowledge Mobility for the Digital Age".

38) See Barbara Cassin, 2014. Dictionary of Untranslatables: A Philosophical Lexicon: Princeton University Press.

39) Salman Rushdie, The Wizard Oz, 2002. London: BFI, Rushdie calls this chant "the least convincing idea of the film" pp. 14-16 while pointing to Dorothy's song, "Over the Rainbow," as a "celebration of Escape" and a "hymn — the hymn—to Elsewhere" (23). Italics in origin.

40) I addressed the question of home at more length in Brydon, "Storying Home: Power and Truth". 
in Bengali doesn't just mean 'home;' it also means 'room' in the way in which it doesn't mean that in Hindi." 41 Spivak muses: "I am at home everywhere and I am not at home anywhere." 42 For her, "home is a kind of direction"43; it is "flexible" 44 , and to "have many home bases ... is one of the ways in which the imagination thrives." 45 That is how I see home too. Some might dismiss this relation to home as the privilege only of the global intellectual, but I think she is gesturing toward something more profound here. Home need not be a monoculture of the mind for anyone because it is framed through direction (that is, through the mobility of orientations and the relations they produce) rather than through stasis. Zygmunt Bauman suggests globalizing processes are rendering everyone now either a tourist or a vagabond (1998). In other words, everyone is now determined, less by their place of origin or habitation, than by how they move through places, their movements differentiated by relations of "privilege or penalty"46. On the other hand, Paul Gilroy identifies two groups of people whose access to the powers of citizenship status is determined, even onto the fourth generation, by the accidents of their birth. "In this schema," Gilroy notes, "the

41) Swapan Chakravorty, Suzana Milevska, and Tani E. Barlow, 2006. Conversations with Gayatri Chakaravorty Spivak (sic) ,London: Seagull, p. 7.

42) Chakravorty et al., Conversations, pp. 19.

43) Chakravorty et al, p. 20.

44) Chakravorty et al, p. 21.

45) Chakravorty et al, p. 21.

46) Sherene Razack, 1998. Looking White People in the Eye: Gender, Race, and Culture in Courtrooms and Classrooms, Toronto: University of Toronto Press, p. 170. 
citizens confront the denizens who exist in a kind of social twilight."47 Citizens and denizens denote two modes of habitation of the same local space, but both derive their meaning from different relations to mobility, Citizens are born where they continue to live; denizens are migrants or the children of migrants who are forever defined by that original act of migration. ${ }^{48}$ Each of these sets of opposing terms signals the difficulty of describing contemporary relations to locality through reversion to the concept of identity alone. Identity itself, as experienced by those living it, is too unstable to be captured within a singular frame of naming. The challenge is how to think such variants as tourist/vagabond and denizen/citizen together in all their nuanced complexity.

\section{Identity and Locality: how are they linked?}

Why is identity so central to literary and cultural studies? And why is it still so tied to locality and monocultures of the mind? These questions have always puzzled me. My first book looked at the fiction of Australian expatriate writer Christina Stead in an effort to understand the twentieth-century stigmas and freedoms attached to expatriation. Stead lived in different parts of the world and wrote of the lives she observed there,

47) Paul Gilroy, 2006. "Colonial Crimes and Convivial Cultures" Rethinking Nordic Colonialism. Act 2: Greenland. April 21-May 14.

48) Such is the situation of the oung people whose lives are followed in Dionne Brand's What We All Long For, discussed later in this paper. 
including workers in a Paris bank, a young woman seeking marriage in New York, and guests staying in a little hotel in Switzerland. She paid a high price for her mobility at a time when authors were tightly linked to national structures of attention. Character and talk drive her books, yet the stereotypical ideas of identity cannot explain them. In my critical work, I realize I have chosen to study writers who challenge conventional notions of identity, and in my theorizing, I address questions of agency through exploring autonomy, transnational literacy, and communal negotiation. Yet I have to recognize that in the current era, questions of identity appear for many people more urgent than ever. Globalization brings both homogenizations in some spheres and an increased tolerance for diversity in others. Both changes can threaten stable notions of identity and the institutional systems that still rely on them.

North-American poet-critic Charles Bernstein suggests that "No issue has dogged poetry so much in the past two decades as identity—national, social, ethnic, racial, and local." 49 Bernstein links identity to place in an unconventional way: "Like the Americas, identity is always plural. And like the Americas, identity is necessarily, a priori, identity-obsessed parts, syncretic and braided, indeed, self-cannibalizing, as surely as the DNA that flows in our psyches and concatenates our mental projections." ${ }^{50}$ Here Bernstein

49) Charles Bernstein, 2011. Attack of the Difficult Poems, Chicago: University of Chicago Press, p. 67.

50) Bernstein, Attack of the Difficult Poems, pp. 67-68. 
mixes older views of identity as "a priori," already established, pre-given, and as composed of a series of discrete parts, with an emergent view of identity as plural, fluid, interactive, and always in transition, a view that shapes how many linguists and poets understand language today, but which remains at odds with the reality that identities may also be experienced as far less fluid in practice. In this paper, I am interested in what Bernstein calls the "mental projections" that may be created through literary and other discursive practices, and their roles in articulating ideas of home beyond monocultures of the mind.

\section{Reconceiving the Local}

Mignolo's advocacy of critical border thinking and Spivak's of planetary both recognize the difficulty of asking Frye's question "where is here?" within post-modern, post-colonial, and posthuman times. Leigh Jenco suggests one way of proceeding might be to "reconceive the local' not as a cultural context that permanently conditions our understanding and argumentative claims, but as a particularized site for the circulation of knowledge"51. I like this view. For Jenco, locality "is not some kind of permanent (albeit constantly penetrated) dwelling place that persists in shaping the entirety of its residents' theorizations" 52 . Rather, "it often

51) Jenco, “Recentering Political Theory," pp. 28.

52) Ibid., p. 38. 
stands as a concentrated site of audiences, sympathies, and standards that generate particular kinds of reflections and render them viable in local (but possibly broader) contexts." ${ }^{3}$ Jenco is looking for a way to think outside Eurocentric categories and Western domination of the disciplines without privileging simplistic and unconvincing notions of local authenticity. By redefining locality as a site of circulating and contending discourses, Jenco complicates the binary of insider/outsider and provides more space for the co-constitution of knowledge by teams of scholars reorganized within "localized communities of knowledge"54 functioning in genuinely reciprocal exchange with such communities elsewhere.

This was the model explored in three recent team projects in which I have been involved: "Globalization and Autonomy," "Building Global Democracy," and "Brazil/Canada Knowledge Exchange." Each sought to create transversal relations across peripheries, either bypassing or marginalizing hegemonic centres of power. These projects confronted the difficulties explored by Jencospecifically, that even scholars based in non-Western parts of the world have still been trained in dominant Eurocentric forms of knowledge production and evaluation. With Jenco, we conclude that "The answer lies in interrogating the assumption that we must either be engaged in reflection that culminates in general, intelligible knowledge about political life [Jenco's area of disciplinary

53) Ibid., p. 38.

54) Ibid., p. 45. 
focus], or we are investigating local contingency." 55 That binary is no longer tenable. We need to explore other options. Tsing makes a similar point in Friction: An Ethnography of Global Connection. She argues the universal/particular binary is an imperialist construction that must be abandoned if decolonization is to proceed. A Translation Studies Forum, "Universalism in Translation Studies," raises these issues in an ongoing discussion inviting further reflections on the role and value of place in translation practices, the value of seeking a standardized language, and the adequacy of current frames for standardization. The contributors ask: does place matter, and if it does, then how does it matter? And how can research, teaching, and translation practices be adapted to find more adequate answers to these questions?

Judy Wakabayashi, in her contribution to this Forum, defines the problem by asking the postcolonial question: "Why is it that non-Western practices and ideas of translation are regarded as particular to their sites of origin yet the same lens is not applied to Western practices and ideas?"56 If we are to move beyond this unjust and inaccurate state of affairs, she argues, then "we need a meta-discourse that is attentive to site-based practices and debates and brings them together to identify genuine commonalities and differences, historicizing translation practices and thinking and recognizing specificity without reifying difference in an unproductive

55) Ibid., p. 51.

56) Judy Wakabayashi, 2014. "Response" in "Translation Studies Forum: Universalism in Translation Studies," Translation Studies 7.1, p. 98. 
manner." 57 This is the daunting task scholars face now, both those of us working with literal translations and those of us working with reading across cultures, including writing within a globalized language such as English with all its local variations.

As an example of how difficult this is, I offer the following anecdote. My Brazil/Canada team set up panel discussion on our transnational literacies theme asking two scholars from each country to explain their site-specific critical literacy practices as teachers and researchers. We hoped through this exercise to learn more about theories and institutional practices arising from each nation and regions within it, yet most presenters chose to describe their work as fully congruent with dominant patterns in the Anglophone world, citing leading Australian, American, and British theorists as models for their work. This experience is a necessary reminder of how powerful the AngloAmerican academy remains globally, and how difficult it is to be heard if one writes outside its norms of intelligibility.

\section{If "I am Where I Think, Where is That?": New Urban Imaginaries}

The titles of two earlier articles where I wrestled with this question show my experimentations with redefining the particular/universal binary. "Earth, World, Planet: Where does

57) Wakabayashi, “Response,” pp. 100-101. 
the Postcolonial Critic Stand?" thinks about expanded understandings of locality offered by three contending names for describing global space. Each name invokes a different kind of orientation to the global. "Cracking Imaginaries: Studying the Global from Canadian Space" approaches similar questions from the opposite direction, a perspective stressing my local situatedness, as a Canadian reader of multicultural texts and as a follower of the debates that are arising around the Winnipeg Museum of Human Rights, which opened in Fall 2014.

Saskia Sassen has drawn attention to the rise of the global city, which is assuming more importance than the nation in some contexts. Some Canadian fiction follows this lead. In TrindadianCanadian Dionne Brand's novel, What We All Long For, Canada is rarely mentioned. Toronto functions as both the setting and a character in this novel. The older generation of her multicultural cast of characters have moved to Toronto from different parts of the country and the world but their children, born in Toronto, think of Toronto as their home and the site of their desires. Each resists the pull of inherited identities and the racialized assumptions about their identity made by enforcers of dominant imaginaries, such as their parents, teachers and the media. Instead, they aspire to forge new ways of listening to the half-heard murmurings of the city and making sense of its meanings. Each feels the pull of family connections but claims the right to forge their own affiliations. Is this a post-national novel about an emerging global 
city 58 , a celebration of "cosmo-multiculturalism" 59 , or is it offering a new way of understanding locality? Here, I argue the latter. 60

The novel begins: "This city hovers above the forty-third parallel; that's illusory of course"61, and continues in this vein, offering some certainty of placement and then immediately problematizing it. The narrator explains: "as at any crossroad there are permutations of existence. People turn into other people imperceptibly, unconsciously, right here in the grumbling [subway] train ... "This guiding voice continues: "Lives in the city are doubled, tripled, conjugated ... In this city, like everywhere, people work, they eat, they drink, they have sex, but it's hard not to wake up here without the certainty of misapprehension" 62 . This is a wonderful phrase for describing the kinds of doublebinds that come with a city formed by immigration and built on unacknowledged "Ojibway land"63: the certainty of misapprehension. In other words, the only thing you can know for certain is that

58) See Sandra Regina Goulart Almeida, 2012. "Unsettling Voices: Dionne Brand's Cosmopolitan Cities," in Crosstalk: Diana Brydon and Marta Dvorak, (eds.), Canadian and Global Imaginaries in Dialogue, Waterloo: Wilfrid Laurier University Press, pp.169-184; Kit Dobson, "'Struggle Work': Global and Urban Citizenship in Dionne Brand's What We All Long For," Studies in Canadian Literature 31.2 (2006): pp. 88104; Molly Littlewood McKibbin, 2008. "The Possibilities of Home: Negotiating City Spaces in Dionne Brand's What We All Long For," Journal of Black Studies 38.3, pp. 502-18.

59) Johansen, Cosmopolitanism and Place, p. 73.

60 ) There are many other ways of reading this complex novel, and much more has been published on it. Here, however, I focus only on interpretations that deal most centrally with locality.

61) Dionne Brand, 2005. What We All Long For, Toronto: Knopf 1.

62) Brand, What We All Long For, p. 5.

63) Ibid., p. 4. 
your knowing is likely mistaken and others' certainties about you are likely to be also. The "certainty of misapprehension" describes a generalized uneasiness with no clear referent.

Brand's Toronto is a city formed, like a coral reef, by the irritants of the world. Chapter Five begins: "A yellow mote of sand dreams in the polyp's eye; the coral needs this pain. The poet Kamau Brathwaite wrote this. It could this city's mantra. It could escape and mingle with the amplifying city, especially on Mondays..." 64 Here a Barbadian poet adds his voice, and the tidalectic rhythms of a life shaped by the sea, to the chorus of an amplifying city many latitudes to the north. For the characters born in Toronto, Toronto is both "this mothering city" 65 and the "surrogate city" 66 , descriptors that mirror their ambivalent feelings of entitlement yet not quite belonging. These secondgeneration Canadians see their immigrant parents as unsuccessful border crossers, workers "in the immigrant sweatshop they call this city" 67 but they themselves, the narrator claims, "are in fact, borderless"68. After the 2002 World Cup, these young people, with parents of Vietnamese, Italian, and Caribbean origin, join the crowds celebrating and singing, "Oh, Pil-seung Korea!" 69 . With the same enthusiasm, they lose themselves in Ornette Coleman's
64) Ibid., p. 53.
65) Ibid., p. 67.
66) Ibid., p. 68.
67) Ibid., p. 212.
68) Ibid., p. 213.
69) Ibid., p. 214. 
music, "The Jungle is a Skyscraper"70, where the point again is to stress appreciation for the dissonance in melody, and the ways in which "Every horn is alone, but they're together, crashing." ${ }^{11}$ This emergent, but significantly only temporary form of postmodern community $^{72}$ is what the artist Tuyen tries to capture in her installations, which are indebted to surrealism while being entirely her own, created in conversation with the city itself. How positively readers are to receive this declaration of borderlessness is disputed, as is its accuracy in describing the lives of these characters and their various modes of inhabiting local space. In its depictions of diasporic, friendship, and non-kinship relations, its mapping of alternative routes through the streets of the city, and its commentary on how various forms of artistic expression (from graffiti to music to installations) seek to engage with what it means to live in post 9/11 Toronto, this novel provides a hopeful but still challenging view of the locality of alterity in early twenty-first century Toronto. Elsewhere, reading the book through the lens of "emotional geographies," I have also suggested it problematizes Pico Iyer's enthusiastic description of Toronto as the ideal global city in his Global Soul73.

70) Ibid., p. 228.

71) Ibid., pp. 228-229.

72) Brand, After the spontaneous identification with Korea's victory, the narrator notes: "She wasn't Korean, of course, but World Cup made her feel that way" p. 204.

73) Diana Brydon, 2006. "A Place on the Map of the World': Locating Hope in Shani Mootoo's He Drown She in the Sea and Dionne Brand's What We All Long For" MaComère 8, p. 104. 
Winnipeg, a smaller city, does not have the resources to qualify as a global city. But it too is a city of immigrants and has the highest indigenous population in the country. Although historically indigenous peoples were confined to Reservations, "more than half of Canada's Native population now resides in cities"74. This is the context addressed in Marvin Francis's long poem, City Treaty. The poem proceeds through a series of dialogues between JOE TB, "a treaty buster" "bush poet" with "one lung left," and a Native Clown who follows him. Joe says: "you cannot shake a clown / that mask sees all"75. Here TB can signify both tuberculosis, a disease that disproportionately plagues indigenous peoples, and treaty busting, an activist challenge to how Canada's identity as a treaty nation has evolved and requires revision through the writing of a new arrangement, a rethinking of the treaty relation through the city. As the poet Francis explains in his proposal description for the creative Master's thesis that became City Treaty, "The main thrust of City Treaty is that treaties are living documents that evolve along with society. Since an increasing percentage of Native people are urban, their perceptions differ from those who signed the original treaties."76 In other words, the kinds of governance questions addressed by the treaties originally signed between the British Crown and the First Peoples of the Treaty One location where Winnipeg now stands

74) Warren Cariou, foreword to Bush Camp by Marvin Francis (Winnipeg: Turnstone, 2009), vii-viii.

75) Marvin Francis, 2002. City Treaty: A Long Poem, Winnipeg: Turnstone, p. 5.

76) Marvin Francis, “Description of Proposal," Archives, University of Manitoba, p. 1. 
require re-interpretation in recognition of changing understandings of time/place relations as well as the different understandings of legal jurisdiction and tradition held by the original signers.

Francis argues that the treaty "documents have become guidelines for the lives of those who have had to accept what their ancestors signed.... Treaties are living proof of the power that words on paper have to influence lives." ${ }^{77}$ Given this power of the treaties as words on paper, City Treaty invokes the example of Shakespeare's Caliban, seizing the language to make it his own. His Joe stirs up a "native tempest"78, combining intertexts from canonical English literature, advertising slogans, and pop culture catchphrases with words borrowed from the many native "word drummers" whose work has led the way toward "righting" the treaties, with write spelled as right to underline the point. ${ }^{79}$ In this way, the poet refuses to limit his imagination to work within a single local tradition, drawing instead on the full ecology of knowledge available to him while processing them through his own local matrix.

Francis's proposal promises: "I want to take the reader on a paper trail into the bush and the city with a storyline that I will label walking in the bush narrative ..." 80 This phrasing recalls the motto of Zapatista Sub-commandant Marcos: "walking while asking questions." According to Ramon Grosfoguel, "Walking while

77) Francis, “Description of Proposal," p. 2.

78) Francis, City Treaty, p. 49.

79) Francis, City Treaty, p. 68.

80) Francis, “Description of Proposal," p. 1. 
asking questions is linked to the Trojolabal understanding of democracy as "commanding while obeying" in which "those who command obey, and those who obey command"81. Like the Zapatistas, Francis's poem constructs "a world in which other worlds fit" ${ }^{\prime 2}$. His poem celebrates transversal, rather than linear, movement: "The form of my long poem will be like the paths in a bush, rhyzomic." 83 His walking marks bush-informed routes through a city whose grid has been designed elsewhere. For Francis, the city has been imposed on the land but remains subject to the land's imperatives. The northern-specific "muskeg metaphors" reclaim the power of language from the imperial "word cannibals" who took the land from its original inhabitants.

The poem is cynical about the history of Canada in which treaties have been signed but not honoured. He claims dismissively: "treaty language / easy translate / you will lose" 84 . In other words, the winners write the history and their versions triumph. That cynicism is deepened when he asks: "how about a / mcTreatyTM / would you like some lies with that?"85-where the trademark symbol after mcTreaty is footnoted as "treaty manuscript." McDonalds has become a global signifier of global capitalism and the prefix "mc" has come to signify commodification in

81) Ramon Grosfoguel, 2012. “Decolonizing Western Uni-verssalism: Decolonial Pluriversalism from Aime Cesaire to the Zapatistas," Transmodernity, Journal of Peripheral Cultural Production of the Luso-Hispanic World 1.3, p. 99.

82) Cited in Grosfoguel, "Decolonizing Western Universalism," p. 99.

83) Francis, "Description of Proposal," p. 2.

84) Francis, City Treaty, p. 49.

85) Ibid., p. 6. 
all its forms. A "mcjob", for example, is slang for a job at McDonalds, poorly paid and insecure. Its use here, tied to the double signification of TM, underlines the close connections between imperialism and capitalism, which in turn link the historical site on which the city was built to the contemporary city of Winnipeg. There is also an unarticulated half rhymelinking "lies" to "fries" through recalling the unspoken McDonalds formula, spoken by all servers: "Would you like some fries with that?" Through this echo, colonial lies mark an automatic betrayal of the original promise of reciprocal negotiation between equals embodied in the treaties from the indigenous perspective.

For Francis, words are both the problem and the solution. His poem retains a faith in the agency of poetry to renew those broken treaty promises. City Treaty has been received "as a streetwise anti-globalization manifesto for the indigenous world"86. The aesthetics of that streetwise position is performed through the interactions of Joe, the contemporary native man in the street, and the Native Clown, a mythic figure "who traditionally questions, mocks, entertains and turns the world inside out," as Francis explains in his MA thesis Proposal. ${ }^{87}$ In the poem, refusing to explain is part of his strategy: "so you have to explain who is this clown / but I won't / I can knot / will not will not"88. By spelling not with a $\mathrm{k}$, he suggests the double bind in which

86) Warren Cariou, 2006. How Come these Guns are so Tall': Anti-corporate Resistance in Marvin Francis's City Treaty, Studies in Canadian Literature 31.1, p. 140.

87) Francis, "Description of Proposal," p. 2.

88) Francis, City Treaty, p. 7. 
unequal cross-cultural explanations find themselves trapped, so that the only way to express agency in this situation is through refusal.

City Treaty rewrites Winnipeg just as Brand rewrites Toronto, each moving perceptions of urban community beyond monocultures of the mind. Each shares an apprehension of the fragility of contemporary city lives. Francis's narrator Joe claims: "we all walk edges uncertain / on border slippery / between... invisible borders stronger than / barb wire / cement our paths to our edgewalking ways." 89 Brand's characters "think they're safe, but they know they're not"90. Each neighbourhood of Brand's Toronto sits "on Ojibway land, but hardly any of them know it or care because that genealogy is willfully untraceable except in the name of the city itself"91. In response to such willfully untraceable prior habitation, City Treaty retraces and updates a Cree genealogy for Winnipeg, and reclaims an indigenous right to relocate the original treaties within indigenous mapping systems while also claiming a Native right to the city. ${ }^{92}$

City Treaty closes by invoking the names of inspirational "word drummers", those published native writers from the United States and Canada who "hurtle / words into that English

89) Ibid., p. 28.

90) Brand, What We All Long For, p. 4.

91) Ibid., p. 4.

92) In "My Urban Rez," Francis writes: "The Native Landscape includes the city, and both the Native communities and society in general must find a way to use the best that the city has to offer to form a site that is beneficial to all" (4). 
landscape like brown beer / bottles tossed from the back seat on a country / road shattering the air turtle words crawl slowly from / the broken glass..." Here, "turtle words" recall "Turtle Island," "the term used by Anishinabe and other Indigenous peoples to describe what is geo-politically known as North America"93. "Turtle words" thus rename locality in reference to the creation stories in which a turtle emerges from a great flood, offering her back as a new home for the indigenous peoples. This mobile locality, turtle island, is alive.

Two texts constitute too small a sample to indicate a larger trend but they do raise questions about the "methodological nationalisms" (Beck) in which literary critics continue to be trained, and through which nation-based studies make their meanings. My point, however, is not to argue against working through national channels to achieve social justice goals. Quite the contrary. Nation-based institutional structures continue to serve important purposes, and in a functioning democracy, they can still remain a citizen's best hope for achieving such goals and for making a difference, through coalitions, on the international stage. In turn, the national imaginaries through which such institutions are formed and sustained depend upon local and regional imaginaries, and on their imbrications within contending visions of the cosmopolitical ${ }^{94}$ and translocated ${ }^{95}$ imaginaries of

93) AiméeCraft, 2013. Breathing Life Into the Stone Fort Treaty: An Anishinabe Understanding of Treaty One, Saskatoon: Purich, p. 123.

94) See Debating Cosmopolitics, ed. Daniele Archibugi and Mathias Koenig-Archibugi, 
transworld entanglements. Revisions of the local such as those offered by Brand and Francis reveal the potential of understanding locality as a living, moving, metamorphosingspace rather than a determinant place of origin.

\section{Conclusion}

This paper has woven together insights from de-colonial, indigenous, postcolonial, and globalization theories to argue for the validity of emerging understandings of locality as a mobile and shape-shifting imaginary that interacts through human engagements with other localities within a shifting global terrain. ${ }^{96}$ It is written out of my own lived experiences a reader and a

ed. London: Verso, 2003 for multiple perspectives on cosmopolitics as the concept of a world politics based on shared democratic values.

95) See Marga Munkelt, Markus Schmitz, Mark Stein, and Silke Stroh, "Introduction: Directions of Translocation -Towards a Critical Spatial Thinking in Postcolonial Studies" for an extended discussion of the possible meanings of this term, ranging from seeing it as "an intermediary term between 'local' and 'global' ... especially suitable for studying connections that are instituted by non-dominant social actors" (xiv) to its usage to describe "multiple crossings, switching back and forth, and transformation" (xxxv) In their Introduction to their edited book, Edward Said's Translocations: Essays in Secular Criticism, Tobias Doring and Mark Stein use translocation to "describe both the disparities and the continuities between two places, fields, or discourses, which are brought together in an argument It thus describes an activity on the reader's or critic's part in exploring such connections and seeing 'complementarity and interdependence' across difference, i.e. without abstracting from particularities nor homogenizing everything into broad and diffuse categories" (4).

96) In Brydon "Migrating Literacies: Redefining Knowledge Mobility for the Digital Age," I begin to develop some of these ideas around changing notions of mobility in globalization. 
teacher in different locations, in the hopes of forging links with readers elsewhere. As Michelle Yeh notes, "meaning is relational" and context is especially important in "transcultural and transnational situations," ${ }^{97}$ which are the contexts of academic work today. In such contexts, "global connections are locally made and therefore variable rather than homogenous." 98 My thinking has been influenced by the work of Kuan-Hsing Chen, who argues in Asia as Method for the necessity of unfolding a concurrent three part program of deimperialization, decolonization, and de-Cold War, launched from and for his part of the world. ${ }^{99}$ Such a program needs to attend to local differences within the region. Tani Barlow has identified "the persistent, lurking desire to flatten out the terrain of colonial modernity in the Asian Pacific arena." This insight leads her to conclude that "Where we are located in the terrain becomes most germane, as pertinent and negotiable as they we are." ${ }^{100}$ Dreams of a post-Cartesian world may be found in the work of theorists and writers from around the world. Those dreams have not yet transformed how knowledge production within the world's universities is either produced or evaluated, but they are shifting understanding, encouraging scholars

97) Rey Chow. (ed.), 2000. "International Theory and the Transnational Critic." In Modern Chinese Literary and Cultural Studies in the Age of Theory: Reimaginaing a Field, Durham: Duke University Press, p. 260.

98) Chris Berry, Fran Martin, and Audrey Yue. "Introduction: Beep-Click-Link" In Mobile Cultures: New Media in Queer Asia, Chris Berry, Fran Martin and Audrey Yue, Durham: Duke University Press.

99) 2010. Asia as Method: Toward Deimperialization. Durham: Duke University Press. 100) Tani E. Barlow. (ed.), 1997. "Introduction: On 'Colonial Modernity" In Formations of Colonial Modernity in East Asia, Durham: Duke University Press, p. 18. 


\section{Diana Brydon}

everywhere to stretch our imaginations and question inherited monocultures of the mind.

\section{Bibliography}

Almeida, Sandra Regina Goulart, 2012. Unsettling Voices: Dionne Brand's Cosmopolitan Cities. Diana Brydon and Marta Dvorak (eds.), In Crosstalk: Canadian and Global Imaginaries in Dialogue, 169-184. Waterloo: Wilfrid Laurier University Press,

Apter, Emily, 2013. Against World Literature: On the Politics of Untranslatability. London: Verso.

Archibugi, Daniele and Mathias Koenig-Archibugi (eds.), 2003. Debating Cosmopolitics. London: Verso.

Barlow, Tani E., 1997. Introduction: On ‘Colonial Modernity', In Formations of Colonial Modernity in East Asia (eds.), Tani E. Barlow. Durham: Duke University Press, 1-20.

Bauman, Zygmunt, 1998. Globalization: The Human Consequences. New York: Columbia University Press.

Beck, Ulrich., 2000. What is Globalization? Malden: Polity.

Bennett, Tony, 2005. Home. In New Keywords: A Revised Vocabulary of Culture and Society, edited by Tony Bennett, Lawrence Grossberg, and Meaghan Morriss, 162-164. Oxford: Blackwell.

Bennett, Tony, Lawrence Grossberg and Meaghan Morriss, (eds.), 2005. New Keywords: A Revised Vocabulary of Culture and Society. Oxford: Blackwell. Bernstein, Charles, 2011. Attack of the Difficult Poems. Chicago: University of Chicago Press. 
Berry, Chris, Fran Martin and Audrey Yue, 2003. Introduction: Beep-ClickLink. In Mobile Cultures: New Media in Queer Asia (eds.), Chris Berry, Fran Martin, and Audrey Yue. Durham: Duke University Press, 1-18.

Brand, Dionne, 2003. What We All Long For. Toronto: Knopf.

Brodber, Erna, 1988. Myal. London: New Beacon.

Brydon, Diana, 2010. Cracking Imaginaries: Studying the Global from Canadian Space. In Rerouting the Postcolonial: New Directions for the New Millennium, edited by Janet Wilson, Cristina Sandru, and Sarah Lawson Welsh, 105117. London: Routledge.

Brydon, Diana, 2010. Earth, World, Planet: Where does the Postcolonial Literary Critic Stand? In Cultural Transformations: Perspectives on Translocation in a Global Age, edited by Chris Prentice, Vijay Devadas, and Henry Johnson, 3-29. Amersterdam: Rodopi.

Brydon, Diana, 2000. It's Time for a New Set of Questions. Essays in Canadian Writing, 71: 54-65.

Brydon, Diana, 2012. Migrating Literacies: Redefining Knowledge Mobility for the Digital Age. Aletria: Revista de estudos de literature 22(3): 13-28.

Brydon, Diana, 2006. 'A Place on the Map of the World': Locating Hope in Shani Mootoo's He Drown She in the Sea and Dionne Brand's What We All Long For. MaComère 8: 94-110.

Brydon, Diana, 2007. Storying Home: Power and Truth. In Tropes and Territories: Short Fiction, Postcolonial Readings, Canadian Writing in Context, edited by Marta Dvorak and W.H. New, 33-48. Montreal: McGill-Queen's University Press.

Cariou, Warren, 2009. Foreword to Bush Camp, by Marvin Francis, vii-xi, Winnipeg: Turnstone.

Cariou, Warren, 2006. How Come these Guns are So Tall: Anti-Corporate Resistance in Marvin Francis's City Treaty. Studies in Canadian Literature 31(1): 148-158. 


\section{Diana Brydon}

Cassin, Barbara (ed.), 2014. Dictionary of Untranslatables: A Philosophical Lexicon, translation edited by Emily Apter, Jacques Lezra, and Michael Wood. Princeton University Press.

Chakravorty, Swapan, Suzana Milevska, Tani E. Barlow, 2006. Conversations with Gayatri Chakaravorty Spivak (sic). London: Seagull.

Chen, Kuan-Hsing, 1998. Introduction: The Decolonizing Question. In Trajectories: Inter-Asia Cultural Studies edited by Kuan-Hsing Chen. London: Routledge.

Chen, Kuan-Hsing, 2010. Asia as Method: Toward Deimperialization. Durham: Duke University Press.

Coleman William D. and Alina Sajed (eds.), 2013. Fifty Key Thinkers on Globalization. London and New York: Routledge.

Craft, Aimée, 2013. Breathing Life Into the Stone Fort Treaty: An Anishinabe Understanding of Treaty One. Saskatoon: Purich.

Dobson, Kit, 2006. 'Struggle Work': Global and Urban Citizenship in Dionne Brand's What We All Long For. Studies in Canadian Literature 31(2), 88-104.

Doring, Tobias and Mark Stein, 2012. Introduction: Edward Said's Translocations. In Edward Said's Translocations: Essays in Secular Criticism, ed. Tobias Doring and Mark Stein. London: Routledge, 1-19.

Dussell, Enrique D., 2012. Transmodernity and Interculturality: An Interpretation from the Perspective of Philosophy of Liberation. Transmodernity: Journal of Peripheral Cultural Production of the Luso-Hispanic World 1(3): 28-59.

Emerson, Caryl and Gary Saul Morson, 2005. Bakhtin, Mikhail. In The Johns Hopkins Guide to Literary Theory \& Criticism. Second Edition. (eds.), Michael Groden, Martin Kreiswirth, and Imre Szeman. Baltimore and London: The Johns Hopkins University Press, 89-95. 
Escobar, Arturo, 2010. Afterword to Globalization and the Decolonial Option, edited by Walter D. Mignolo and Arturo Escobar, 391-399. London: Routledge, 391-399.

Francis, Marvin, 2002. City Treaty: a long poem. Winnipeg: Turnstone.

Francis, Marvin, Description of Proposal. Marvin Francis Fonds. Archives. University of Manitoba.

Francis, Marvin, 2004. My Urban Rez. Canadian Dimension.

Frye, Northrop, 1945. Conclusion to a Literary History of Canada. In The Bush Garden: Essays on the Canadian Imagination, edited by Carl F. Klinck. Toronto: UTP, Retrieved online via http://northropfrye-hebushgarden. blogspot.ca/2009/02/conclusion-to-literary-history-of.html

Gilroy, Paul, 2006. Colonial Crimes and Convivial Cultures. Rethinking Nordic Colonialism. Act 2: Greenland.

Grosfoguel, Ramon, 2012. Decolonizing Western Uni-verssalism: Decolonial Pluri-versalism from Aime Cesaire to the Zapatistas. Transmodernity: Journal of Peripheral Cultural Production of the Luso-Hispanic World 1(3): 88-104.

Harris, Wilson, 1983. The Womb of Space: The Cross-Cultural Imagination. London: Greenwood.

Honig, Bonnie, 2001. Democracy and the Foreigner. Princeton: Princeton University Press.

Iyer, Pico, 2001. The Global Soul: Jet Lag, Shopping Malls and the Search for Home. New York: Vintage.

Jenco, Leigh K., 2011. Recentering Political Theory: The Promise of Mobile Locality. Cultural Critique 79: 27-59.

Johansen, Emily, 2014. Cosmopolitanism and Place: Spatial Forms in Contemporary Anglophone Literature. London: Palgrave Macmillan.

Lionnet, Francoise and Shu-mei Shih (eds.), 2011. Introduction to The Creolization of Theory. Durham: Duke University Press. 


\section{Diana Brydon}

Mao, LuMing, 2013. Beyond Bias, Binary, and Border: Mapping out the Future of Comparative Rhetoric. Rhetoric Society Quarterly 43(3): 209225.

McKibbin, Molly Littlewood, 2008. The Possibilities of Home: Negotiating City Spaces in Dionne Brand's What We All Long For. Journal of Black Studies 38(3): 502-18.

McLeod, Neal, 2007. Cree Narrative Memory: From Treaties to Contemporary Times. Saskatoon: Purich.

Mignolo, Walter D., Introduction: Coloniality of Power and De-Colonial Thinking, In Mignolo and Escobar (eds.), 1-21.

Mignolo, Walter D. and Arturo Escobar (eds.), 2010. Globalization and the Decolonial Option. London: Routledge.

Mignolo, Walter D., 2011. I am Where I Think: Remapping the Order of Knowing. In The Creolization of Theory, edited by Francoise Lionnet and Shu-mei Shih, 159-192. Durham: Duke University Press.

Munkelt, Marga, Markus Schmitz, Mark Stein, and Silke Stroh. 2013. Introduction: Directions of Translocation - Towards a Critical Spatial Thinking in Postcolonial Studies. In Postcolonial Translocations: Cultural Representation and Critical Spatial Thinking. Amsterdam: Rodopi.

Neigh, Janet, 2014 Dreams of Uncommon Languages: Transnational Feminist Pedagogy and Multilingual Poetics. Feminist Formations 20(1): 70-92.

Razack, Sherene, 1998. Looking White People in the Eye: Gender, Race, and Culture in Courtrooms and Classrooms. Toronto: University of Toronto Press.

Rushdie, Salman, 2002. The Wizard Oz. London: BFI,

Santos, Boaventura de Sousa, 2007. Another Knowledge is Possible: Beyond Northern Epistemologies. London: Verso, Sassen, Saskia. The Global City: Introducing a Concept. The Brown Journal of World Affairs XI(2) (Winter/Spring 2005): 27-43. 
Mobile Localities Beyond Monocultures of the Mind

Shiva, Vandana, 1993. Monocultures of the Mind. Trumpeter 10(4).

Spivak, Gayatri Chakravorty, 2012. An Aesthetic Education in the Era of Globalization. Harvard University Press.

Spivak, Gayatri Chakravorty, 2003. Death of a Discipline. New York: Columbia University Press, Translation Studies Forum: Universalism in Translation Studies. Translation Studies 7(1): 82-105.

Tsing, Anna Lowenhaupt, 2005. Friction: An Ethnography of Global Connection. Princeton: Princeton University Press.

Wakabayashi, Judy, 2014. Response. In Translation Studies Forum: Universalism in Translation Studies. Translation Studies 7(1): 97-101.

Williams, Raymond, 1976. Keywords: A Vocabulary of Culture and Society. London: Croom Helm.

Yeh, Michelle, 2000. International Theory and the Transnational Critic. In Modern Chinese Literary and Cultural Studies in the Age of Theory: Reimagining a Field (ed.), Rey Chow. Durham: Duke University Press, 251-280. 
